\title{
Jarai formulaic sayings: Hook rhyme \& the nature of binarity in folk verse*
}

\author{
Joshua M. Jensen \\ The University of Texas at Arlington
}

A common pattern that emerges in folk poetry around the world is the grouping of lines into couplets and of couplets into quatrains (Burling 1966, Hayes \& Kaun 1996, Hayes \& MacEachern 1998), as schematized in Hayes \& MacEachern (1998):

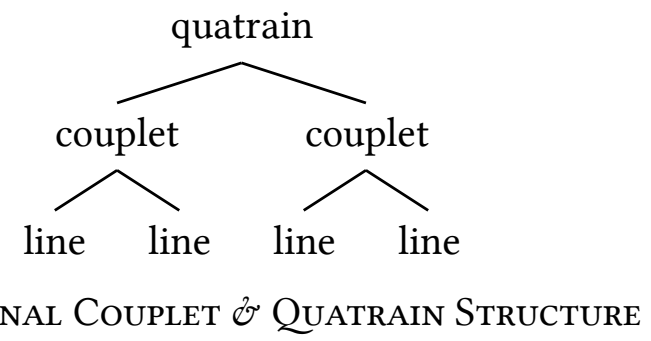

In this paper, I examine how lines form larger constituents in folk verse in Jarai (Chamic, Austronesian; Vietnam). The particular verse form is the Jarai formulaic saying. I gathered much of the data from Jarai consultants in Dallas; other data is from Dournes (1976).

Jarai formulaic sayings are oral poems, typically embedded in narratives. These poems are characterized in part by their rhyme scheme. Example (1) nicely illustrates the form (rhyming syllables are bolded throughout; all poems are cited in complete form).

(1) 3-line poem (Đun Siu) ${ }^{1}$
a. amı̆ ih kăn pha
Your mother won't allow
mother 2s not allow
Your father won't permit
b. ama ih kăn brơi
Your brothers and sisters don't care for me
father 2 s not permit
c. ayŏng adơi ih kăn khăp
siblings 2 s not love

*Thank you to Đun Siu and H'he Siu, the consultants who supplied most of the poetry examined in this paper; YBai Romah, who interpreted \& assisted me in Charlotte, NC; Lap Siu, whose advice, insights, interpreting, and transcribing made this research possible; the College of Liberal Arts at UT Arlington, for funding that assisted in the data-gathering; Colleen Fitzgerald for pushing my analysis and organization forward; Joseph Sabbagh, for a helpful discussion of multiple dominance and constituency in syntax; and John Frampton, for extensive help in the layout of my figures.

${ }^{1}$ All transcriptions use the Jarai orthography, which is reasonably transparent to the phonology and whose glyphs are close to their IPA look-alikes. Unfamiliar glyphs are as follows: OBSTRUANTS: $\mathrm{b}=\mathrm{Pb}, \mathrm{d}=\mathrm{dd}$, $\breve{\mathrm{V}} \#=\mathrm{V}$; ;LIDES: $\mathrm{Vo}=\mathrm{Vw}, \mathrm{Vi}=\mathrm{Vj}$; VOWELs: $\hat{\mathrm{a}}=a, \mathrm{o}=a, \hat{\mathrm{o}}=\mathrm{o}, \mathrm{o}=\partial, \mathrm{u}=\dot{\mathrm{i}}$. 
I argue that lines in Jarai formulaic sayings are grouped in a strictly binary fashion to create couplets, and every line is parsed by at least one couplet. Furthermore, couplets overlap such that a line can be dominated by two couplets.

The most salient aspect of Jarai formulaic sayings is the rhyme structure: Hook rhymes join the last syllable of one line with a non-final syllable of the next line. ${ }^{2}$ As (2) illustrates, each line is linked with the line before it through one hook-rhyme pairing, and with the line after it through a different hook-rhyme pairing.

(2) 4-line poem (H'he Siu)
a. drơi čĭm phì
CLF bird Phii'
The (beautiful) Pi' bird
The skin of the An bird
b. klǐ čĭm ã
skin bird An
The eye of the grass-like forrest
The lips while red
c. mơta trăng glai
eye grassy forest
d. buai lŏm thet
lips while red

In the 125 rhyme pairs I have examined, the second member of the rhyme pair is usually at the left edge of the line (66\%) or one word away from the left edge (18\%). When the second rhyme fellow is non-initial, the initial position is often occupied by a repeated word or phrase, as in (3).

(3) 3-line poem (Lap Siu)
a. (ih kar hăng)
2s similar to
(You are like)
The small bamboo already pruned
b. phŭn ajŭt arăng čram trunk small.bamboo they prune The large bamboo already claimed
c. phŭn kram arăng dje trunk large.bamboo they claim
d. phŭn ale arăng koh trunk small.bamboo they cut

Jarai formulaic sayings can be as short as two lines, but there is apparently no maximal number of lines. The total number of lines can be even, as in example (2), or odd, as in example (4).

\footnotetext{
${ }^{2}$ The term hook rhyme is not original with me. Wilson (1990) uses the term to translate Willi Krogmann's Hakenreim.
} 
(4) 7-line poem (H'he Siu)
a. čư pha-ria mountain different
b. ia pha nao water different go
c. plao pha dỗ islet different stay
d. anŏ pha ngui
residence different visit
e. apui pha diang
fire different make.warm
f. sang pha đ̆ house different climb
g. anih pha-ria klah place different divide
Different mountains
Walking along different waters
Living on different islets
Visiting different residences
Different fires warming us
Ascending into different homes
Curtaining off different quarters

Out of the 63 formulaic sayings that I analyzed-a total of 195 lines-31 poems have an odd number of lines. Clearly, Jarai formulaic sayings with an odd-number of lines are by no means exceptional. But poems with an odd number of lines receive an inadequate parsing using traditional couplets, because at least one line must be left uncoupled.

Thus, Jarai formulaic sayings raise the question: What is the nature of line-grouping constituents in Jarai formulaic sayings?

My central claim is that all lines are parsed into couplets, but overlapping constituency is permitted, so each interior line is dominated by 2 couplets. This overlapping couplet constituency-which is signaled by the hook rhymes-can be visualized as in these figures:

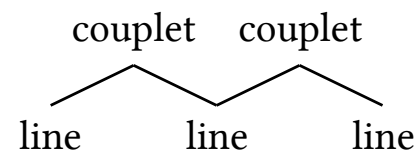

OVERLAPPING COUPLETS FOR 3 LINES

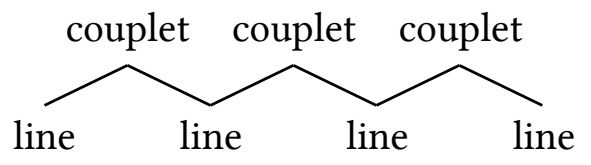

OVERLAPPING COUPLETS FOR 4 LINES

My analysis gives several desirable results: (1) binarity is respected \& minimal poem length is predicted; (2) every line is parsed into a couplet; (3) a formal domain (the couplet) is available to constrain the placement of rhymes; (4) every rhyme pair is given equal status; and (5) freedom of poem length (odd or even number of lines) is predicted.

This paper describes a novel poetic form, the formulaic saying, in an understudied language, Jarai, adding to the growing literature of formal approaches to meter in non-Western languages (among others, Prince 1989, Fitzgerald 1998, 2006, and Cole \& Miyashita 2006). Additionally, I argue here that a binary grouping constraint joins lines into constituents, and that these constituents (the couplets) overlap. This analysis has implications for the representation of line constituency in the generative meter tradition, as well as offering a new parameter (overlapping line constituency) for the typology of verse forms. 
Burling, Robbins. 1966. The metrics of children's verse: A cross-linguistic study. American Anthropologist 68.1418-1441.

Cole, Deborah, \& Mizuki Miyashita. 2006. The function of pauses in metrical studies: Acoustic evidence from Japanese verse. Formal Approaches to Poetry: Recent Developments in Metrics, ed. by B. Elan Dresher and Nila Friedberg. 173-192. Berlin: Mouton de Gruyter.

Dournes, Jacques. 1976. Le parler des förai et le style oral de leur expression. Paris: Publications Orientalistes de France.

Fitzgerald, Colleen M. 1998. The Meter of Tohono O’odham Songs. International fournal of American Linguistics 64.1-36.

Fitzgerald, Colleen M. 2006. Iambic Meter in Somali. Formal Approaches to Poetry: Recent Developments in Metrics, ed. by Elan Dresher \& Nila Friedberg, 193-207. Berlin: Mouton de Gruyter.

Hayes, Bruce P., \& Abigail Kaun. 1996. The role of phonological phrasing in sung and chanted verse. Linguistic Review 13.243-303.

Hayes, Bruce P., \& Margaret MacEachern. 1998. Quatrain form in English folk verse. Language 74.473-507.

Prince, Alan. 1989. Metrical forms. Phonetics and Phonology 1: Rhythm and Meter, ed. by Paul Kiparsky and Gilbert Youmans, 45-80. San Diego: Academic Press.

Wilson, Joseph. 1990. Hook-rhyme in Runes, Notably Högby. Crossings-Kreuzungen: A Festschrift for Helmut Kreuzer, ed. by Edward R. Haymes. Columbia, SC: Camden House. 